\title{
Terminated marketing order provided resources to California peach and nectarine growers
}

The authors found that industry information provided via marketing orders was a significant factor for respondents who voted to continue the orders.

by Zoë Plakias, Rachael Goodhue and Jeffrey Williams

Online: https://doi.org/10.3733/ca.2020a0023

n 2011, growers of fresh peaches and nectarines in California voted in a referendum to terminate the two federal marketing orders that enabled collective funding of marketing and production research, market development and enforcement of quality standards. These marketing orders, formed and continued through regular grower votes and U.S. Department of Agriculture (USDA) approval, had existed for more than 50 years (Federal Register 2011a). The goal of these marketing orders was to stimulate consumer demand for the crops via marketing and production research, to lower production costs via production research, and to maintain a positive industry reputation among consumers via quality standards. The orders were terminated after they failed to meet the voting threshold needed for continuation. The USDA cited increases in on-farm research and private quality standards imposed by retailers as reasons for the lack of sufficient grower support (Federal Register 2011b).

\section{Abstract}

Marketing orders allow farmers to collectively fund industry-wide services that may be difficult to provide through a voluntary approach. But not all farmers support collective approaches. We employed ballot data from U.S. Department of Agriculture and survey data we collected to explore why farmers in California voted to terminate the federal fresh peach and nectarine marketing orders in 2011 and the implications of this termination. Even after controlling for other factors, we found that farmers who produced more were significantly less likely to vote for continuation. We also found that detailed industry information provided via the marketing orders was significantly more important to respondents voting for continuation, and respondents with more organic production were significantly more likely to vote for continuation. These results suggest farmers may have lost important production and marketing resources due to termination of the orders, with evidence that smaller farms were more affected. This termination may thus have accelerated the exit of farmers from this industry.

Modern marketing orders must adapt to meet the diverse and evolving needs of the growers in their industries. 
Continuation of the marketing orders required support from either (1) two-thirds of those voting or (2) producers of two-thirds of the output of those voting. This voting rule is the standard rule for federal marketing orders; the rules differ for federal research, commodity and promotion programs and similar types of state-level organizations. Among both fresh peach and nectarine growers, more than $60 \%$ of farmers voting in the referendum voted for continuation, but in each case they represented just over $30 \%$ of the total output of those voting (Federal Register 2011a). Although very close to meeting the first voting threshold, because neither threshold was met, the marketing orders for both crops were terminated. When voting, producers could

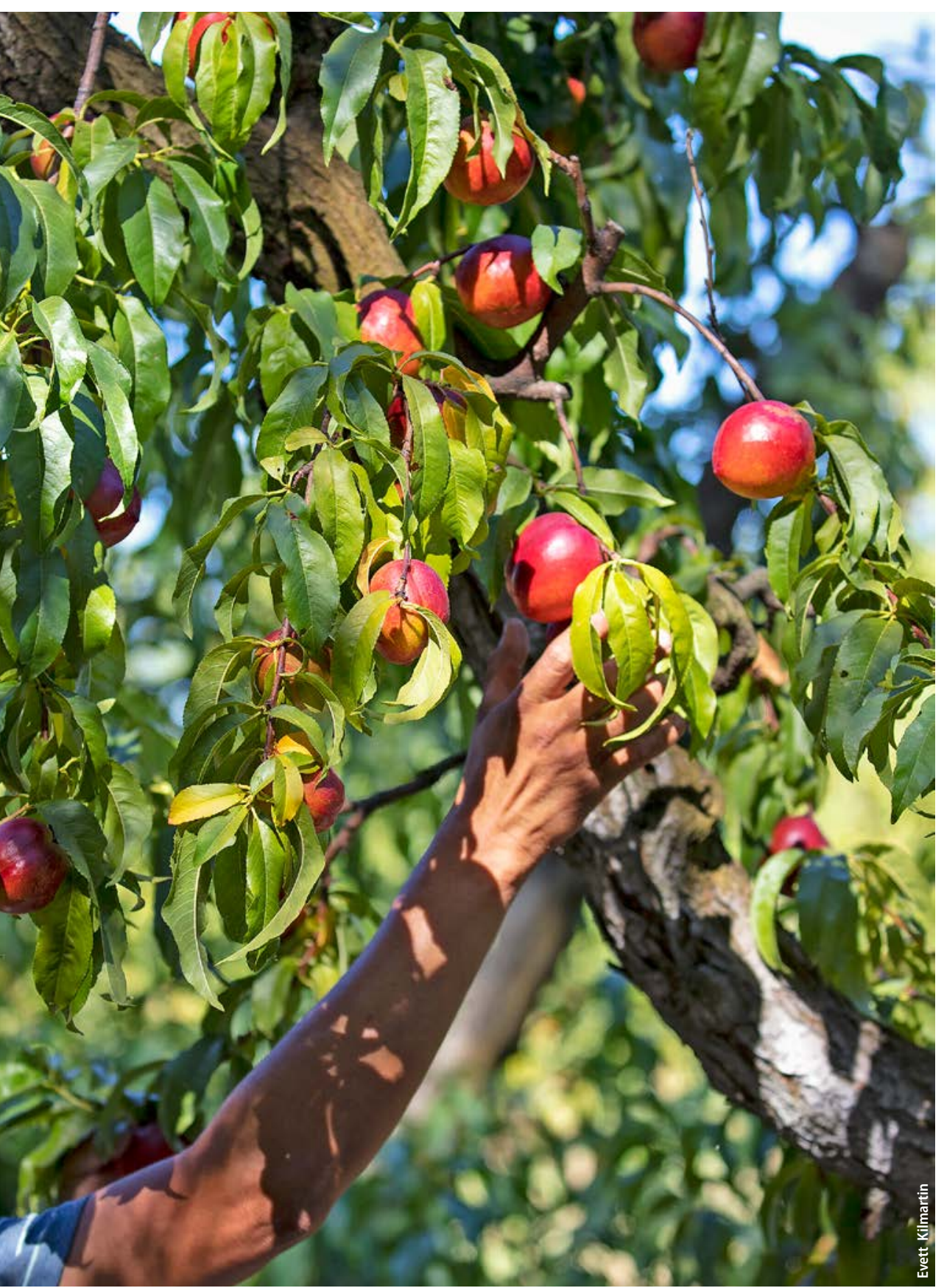

select either "continue" or "terminate" on their ballot for each crop, so we refer to the "continuance referendum" in line with USDA terminology and the "termination vote" to indicate the referendum's outcome for both crops.

The results from this referendum suggest an important link between the value of the marketing orders to farmers and farm size (specifically, farms' production of fresh peaches and nectarines). However, farm size was not the only factor in farmers' votes. We examined which characteristics of both farms and farmers predicted farmers' support for these marketing orders, and whether these factors are consistent with the reasons for termination the USDA highlighted in their justification for the termination (Federal Register 2011b). We also analyzed farmers' behavior after the termination of the orders. To carry out this work, we used survey data collected from farmers about their fresh peach and nectarine production and USDA ballot data from the 2011 referendum containing farmers' votes.

Marketing orders and related programs (often collectively referred to as "check-offs") are under increasing political scrutiny for the role they play as government-enforced, industry-led organizations (for example, Sen. Elizabeth Warren specifically referenced check-off programs in her agricultural policy platform during her presidential campaign, suggesting they should be made voluntary [Warren 2019]). This scrutiny comes in part from the fact that these organizations have distributional consequences and may, whether unintentionally or intentionally, favor a subset of producers. A U.S. Supreme Court justice even recently suggested during oral arguments that checkoffs are an antiquated form of policy (U.S. Supreme Court 2013). Nevertheless, even as existing check-offs are challenged or terminated, new ones are being established. For example, pecan growers in 15 states voted in March 2016 to approve a new federal marketing order in their industry (Menayang 2016). As industries become more varied in terms of size, marketing channels and production practices, understanding the tensions arising from the use of industry-wide mandatory organizations and the potential benefits and costs of these organizations is increasingly important. Additional information on the history of check-offs and their controversy can be found in Crespi and Sexton (2001) and Williams and Capps (2006).

Our work is of particular relevance to diversified California farmers, who may grow multiple crops with mandatory check-off programs. In fact, there are currently 50 state-level commissions and councils (administered by the California Department of Food and Agriculture, or CDFA), 11 federal marketing orders (administered by the USDA) and 16 federal research and commodity promotion boards (also administered by the USDA) operating in nearly as many agricultural industries within the state. These check-off programs differ slightly in how they are administered depending on the administering body and the type of 
organization, but they all follow a similar process for formation and continuation. Their formation is initiated via petition by a group of farmers or handlers (a packer or shipper of peaches and nectarines, sometimes affiliated with a specific grower). This petition is followed by an administrative review (by the USDA, or by the equivalent state agency in the case of a state group). If the administering agency deems the organization potentially beneficial to farmers in the industry, formation is then put to a vote in a referendum of affected growers and/or handlers. The marketing order is officially formed if a certain voting threshold is met, with final approval in the hands of the secretary of agriculture (state or federal, depending on the organization).

In the years that follow, regular referendum votes (generally every 5 years) are then required by law and administered by the USDA or equivalent state agency to determine whether or not farmers continue their support. Referendum votes are also held if farmers and/or handlers want to make significant changes to the orders (called a major amendment). Continuation of the organization or changes to the organization are contingent on the outcome of these votes and subject to final approval by the relevant secretary of agriculture. Although federally administered, federal marketing orders can applied to a limited geographic area (e.g., a single state), which was the case with the peach and nectarine marketing orders we studied.

Our work contributes to a growing academic literature on the mandatory nature of check-offs and their use. One set of analyses has used theory and/or simulations to measure the expected behavior of farmers or voting outcomes in check-off referenda (e.g., Plakias and Goodhue 2015). Other theoretical work explores the differential benefits of generic promotion among diverse farmers but does not consider other check-off activities (e.g., Zheng, Bar and Kaiser 2010). Additional relevant literature explores voting and the mandatory nature of check-offs using experimental techniques (e.g., Liaukonyte et al. 2014). Finally, there are empirical analyses that use data collected from farmers to explore hypothetical or real voting outcomes (e.g., McLaughlin et al. 2014). Our work contributes to this literature by providing an analysis of a real organization, combining survey and ballot data, and considering the situation at the termination of a marketing order.

\section{Termination vote in context}

Federal marketing orders for peaches (no. 917) and nectarines (no. 916) were established in 1939 and 1958, respectively, and were administered under the California Tree Fruit Agreement (CTFA), established in 1933. These orders were focused on peaches for fresh markets specifically, generally varieties known as "freestone" peaches ("cling" varieties of peaches, which were used more commonly in processing due to the challenges of separating the pit from the flesh of the fruit, had their own separate marketing order). Figure 1 highlights

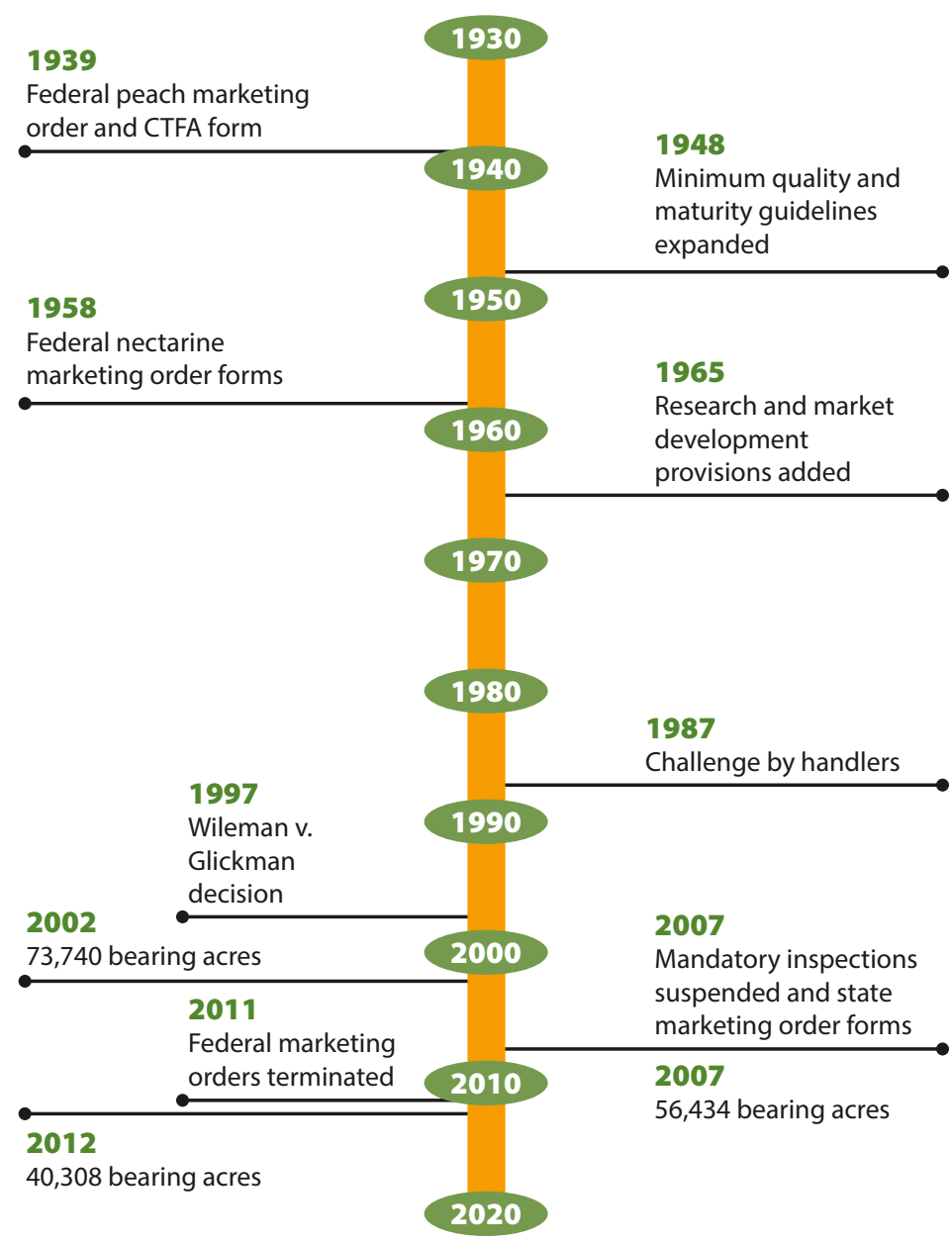

FIG. 1. Fresh peach and nectarine industry and marketing order timeline.

some key dates in the history of the marketing orders. Over time, certain provisions were added to the orders as the industry's focus shifted; in particular, the role of maturity became increasingly important. As any consumer of peaches knows, the taste difference between a juicy, ripe peach and a mealy, unripe peach is substantial, and growers and marketers of peaches recognized the importance of maturity.

By the 1980s, the focus of both marketing orders was generic promotion plus maturity and size standards as indicators of quality (CTFA 1983). Then, in 1987, a group of handlers petitioned the U.S. secretary of agriculture, challenging both the promotion and quality standard provisions of the marketing orders (Crespi 2003). Although the challenges to quality standards were dismissed, the First Amendment challenge to the orders' generic promotion provisions went to the Supreme Court, which ruled in 1997 the provisions were constitutional (U.S. Supreme Court 1997). Despite this ruling, over time the industry discontinued some of its promotion activities as more and more growers and handlers engaged in their own marketing.

In the decade leading up to the termination of the orders, the industry was changing. Respondents to our 
survey and industry leaders indicated high production levels and low prices reduced profits, which led to consolidation and acreage reduction (Sparks 2014). Figure 1 shows the freestone peach acreage bearing from the 2002, 2007 and 2012 USDA Censuses of Agriculture to highlight this contraction in acreage over time (NASS 2020). Concurrently, retailers, who were engaging directly with the largest producers and handlers, were adopting private quality standards, which were sometimes at odds with the standards of the marketing order. Conversations with some industry members and statements from several of our survey respondents suggest that for growers and handlers engaged with these large buyers, this made the order restrictive rather than helpful. However, for growers without direct relationships with buyers and their own recognizable brand, collective standards enforced by the marketing order likely still provided an effective mode for signaling quality to potential buyers. There was a cost to these standards, however - growers and handlers were required to pay for inspections and audits associated with the standards via a small per unit assessment on output, which may have seemed particularly large when industry profitability was at a low.

Not surprisingly, this high cost of the marketing order relative to profit margins highlighted by some survey respondents and the perceived (or actual) differences in the benefits of the marketing orders across growers led the industry to suspend mandatory inspections under the federal orders in 2007. The mandatory inspections were replaced by voluntary inspections administered by a new state-administered marketing order for the same crops. However, farmers who voluntarily labeled their output as "California Well Matured" were still required to meet the grade and size requirements of the federal standard (Federal Register 2007). This allowed those growers or handlers who were not engaged in their own marketing to send a quality signal to prospective buyers while lifting restrictions on those who wanted to meet private quality standards.

In addition to the activities of the marketing orders it administered, the CTFA annual report provided detailed industry information. The purpose of this report was to inform farmers, handlers and regulators so they could better manage quality (CTFA 1958). The information collected expanded over time. By 2007, the annual report provided disaggregated information on shipments by variety, container size, time period,

TABLE 1. Referendum votes, 2011

\begin{tabular}{|c|c|c|c|c|}
\hline & $\begin{array}{c}\text { Ballot } \\
\quad N\end{array}$ & Share & $\begin{array}{c}\text { Survey } \\
N\end{array}$ & Share \\
\hline Vote for peach order continuation (V) & 102 & 0.61 & 37 & 0.38 \\
\hline Vote for nectarine order continuation (V) & 99 & 0.63 & 30 & 0.37 \\
\hline Vote for peach order continuation (Q) & 101 & 0.36 & 31 & 0.35 \\
\hline Vote for nectarine order continuation (Q) & 99 & 0.41 & 27 & 0.21 \\
\hline
\end{tabular}

region size and maturity grade and information on variety sales, rootstock varieties and harvest dates (CTFA 2007).

The state marketing orders were terminated in 2010 after a failed continuance referendum. The federal marketing order referendum occurred several months later in 2011. At the time, the marketing orders' activities included marketing and production research and regulation of voluntary standards as described above. Assessment rates were $\$ 0.028$ per 25 -pound container of nectarines and $\$ 0.026$ per 25 -pound container of peaches, which represent $0.40 \%$ and $0.46 \%$, respectively, of the 2010 average prices received (Federal Register 2010a; NASS 2020). The failed continuance referendum led to termination of the marketing orders and the CTFA closed up shop shortly thereafter.

\section{Ballot and survey data collected}

We used two data sets to examine the votes in these industries. One consists of all referendum ballots collected by the USDA's Agricultural Marketing Service (AMS) - a population of 104 growers. This data set is not a sample but encompasses all voters. Why so few voted is a key question.

The second data set was collected via a 2015 mail survey of California peach and nectarine farmers; we sent a pre-survey letter to each farmer and then sent the full survey twice (a copy of the survey is available by request from the authors). Of the 380 unique farmers surveyed (all peach and nectarine farmers with up-to-date addresses in 2015 who were eligible to vote in the 2011 referendum), we received 65 responses, for a response rate of $17.1 \%$. Fifty-seven of the 65 surveys we received were complete enough to be used in our analysis in some way, resulting in a final response rate of $15.0 \%$. Although this number is low, it is in line with other recent research in this area (e.g., McLaughlin et al. [2014] report a response rate of only $8 \%$ ).

Of the responses to questions about participation in the referendum, $23 \%$ growing each crop either did not vote, could not remember if they voted or preferred not to say. Lack of response was likely driven by the length of the survey (11 pages total) and the lack of current relevance to farmers, given that the marketing orders were terminated several years prior to data collection, and there was structural change in the industry that led to exit, as discussed in the previous section. However, when we consider the respondents who said they voted in the 2011 referendum as a share of all 2011 referendum voters, the response rate was considerably higher, with $30.7 \%$ and $30.3 \%$ of peach and nectarine voters in the 2011 referendum responding, respectively. These numbers suggest that farmers who were more likely to have voted were also significantly more likely to respond to the survey. Thus, in our analysis we only consider survey respondents who reported how they voted.

Table 1 presents these voting results tabulated directly from the USDA AMS ballot data as well as the 


\section{Compared to the population} of referendum voters, survey respondents who voted were less likely to report voting for continuation and represented a smaller share of volume among those voting for nectarines only.

self-reported votes of the survey respondents by the number of farmers voting for continuation $(\mathrm{V})$ and their share of all voters' production (Q). Among survey respondents who voted, nearly $40 \%$ growing each fruit reported voting for continuation. Compared to the population of referendum voters, survey respondents who voted were less likely to report voting for continuation and represented a smaller share of volume among those voting for nectarines only. All respondents who produced both peaches and nectarines voted to continue both or terminate both (not shown).

Table 2 displays additional summary statistics for the ballot and survey data. Results from two different statistical tests used to compare the ballot and survey data sets suggest that relative to the population of referendum voters, survey respondents had significantly lower peach and nectarine yields, were significantly less likely to vote for continuation of the marketing order, and were significantly less likely to produce both freestone peaches and nectarines, measured in annual production of 25-pound containers. These differences further suggest that survey respondents may not be representative of referendum voters, an issue we attempt to address in our analysis.

The operator in table 2 refers to the voter (ballot data) or survey respondent (survey data). In addition to the data reported in table 2 , some voters provided information about their farms' business structures and locations on their ballot. Corporation is the most common business structure, reported by more than half of voters who reported their business structure (not shown). Referendum voters were primarily located in Fresno, Tulare and Kings counties, and nearly $90 \%$ of them had peach and/or nectarine production in one of these counties at the time of the referendum. In the survey, more than $30 \%$ of farm operations reported having more than $\$ 1$ million dollars in gross farm income in 2010; this is the modal income category. Approximately two-thirds of respondents had a bachelor's degree or higher at the time of the survey in 2015.

\section{Data sets combined to reduce bias}

We empirically analyzed the relationship between farm and farmer characteristics and the probability of farmer voting for continuation using a method called binomial logit regression. We first estimated the relationship of variables available from the USDA referendum ballots to the probability of voting for continuation, then conducted a similar procedure using the survey data. Analyzing both data sets has two advantages. First, while the ballot data set represents the population of voters, it does not include all the variables that might be expected to predict farmers' votes. The survey data set enabled us to incorporate these additional characteristics. Second, although the ballot data and survey did not allow us to exactly match individuals across the two data sets, we were able to match survey respondents to similar voters and to see which referendum voters were the most likely to be in our set of survey respondents.

We then used this information to weight the survey observations to partially account for survey respondents' probability of responding to the survey. Matched referendum/survey voters with a lower predicted probability of responding to the survey who responded anyway were given greater weight to account for the fact that they were underrepresented in our survey data.

This procedure allowed us to address some of the bias that comes from the differences we observed between the survey respondents and the population of referendum voters (further details of this empirical procedure, called propensity score weighting, are available by request). For the regressions using ballot data, we report

TABLE 2. Peach and nectarine operation and operator characteristics in 2010

\begin{tabular}{|c|c|c|c|c|c|c|}
\hline \multirow{2}{*}{$\begin{array}{l}\text { Operation } \\
\text { and operator } \\
\text { characteristics }\end{array}$} & \multicolumn{3}{|c|}{ Ballot } & \multicolumn{3}{|c|}{ Survey } \\
\hline & $N$ & Mean/\% & Std dev & $N$ & Mean/\% & Std dev \\
\hline $\begin{array}{l}\text { Containers of } \\
\text { peaches }(1,000 s)\end{array}$ & 101 & 121.54 & 242.89 & 48 & 66.57 & 200.13 \\
\hline $\begin{array}{l}\text { Containers } \\
\text { of nectarines } \\
(1,000 \mathrm{~s})\end{array}$ & 98 & 109.92 & 212.72 & 48 & 29.05 & 52.73 \\
\hline $\begin{array}{l}\text { Acres of peaches/ } \\
\text { nectarines }\end{array}$ & 108 & 287.58 & 584.91 & 50 & 146.98 & 222.81 \\
\hline $\begin{array}{l}\text { Markets peaches } \\
\text { only (\%) }\end{array}$ & 111 & 11.71 & & 46 & 23.91 & \\
\hline $\begin{array}{l}\text { Markets } \\
\text { nectarines only } \\
(\%)\end{array}$ & 111 & 8.11 & & 46 & 13.04 & \\
\hline $\begin{array}{l}\text { Markets both } \\
\text { fruits (\%) }\end{array}$ & 111 & 81.08 & & 46 & 63.04 & \\
\hline $\begin{array}{l}\text { Organic peach } \\
\text { and nectarine } \\
\text { production }(\%)\end{array}$ & & & & 46 & 22.63 & 41.67 \\
\hline $\begin{array}{l}\text { Income from } \\
\text { peaches and } \\
\text { nectarines (\%) }\end{array}$ & & & & 47 & 56.07 & 34.67 \\
\hline Age & & & & 52 & 60.31 & 11.96 \\
\hline $\begin{array}{l}\text { Years of experience } \\
\text { growing peaches } \\
\text { and nectarines }\end{array}$ & & & & 56 & 29.09 & 14.20 \\
\hline Male (\%) & & & & 54 & 98.15 & \\
\hline $\begin{array}{l}\text { Farming is sole } \\
\text { occupation (\%) }\end{array}$ & & & & 57 & 64.91 & \\
\hline
\end{tabular}


the model with and without the business type variable, as not all voters provided this information on their ballot. For the regressions using survey data we provide the results with and without the weights we calculated to address bias.

\section{Size is one factor in farmer votes}

Columns 1 and 2 (table 3) report the results of the regressions exploring the relationship of peach and nectarine farm and farmer characteristics to vote choice using ballot data. The reported values tell us the change in the probability of voting for continuation given a one-unit change in the variable indicated in that row at its average (known as the marginal effect at the mean). The first column includes all referendum voters, while the second includes only the subset of referendum voters who reported information about their business

TABLE 3. Effects of farm and farmer characteristics on probability of voting for continuation of peach $(\mathrm{P})$ and nectarine $(\mathrm{N})$ marketing orders $\dagger$

\begin{tabular}{|c|c|c|c|c|}
\hline \multirow{3}{*}{$\begin{array}{c}\text { Farm and farmer } \\
\text { characteristics }\end{array}$} & \multicolumn{4}{|c|}{ Marginal effects at mean from logit regressions } \\
\hline & \multicolumn{2}{|c|}{ Ballot data } & \multicolumn{2}{|c|}{ Survey data } \\
\hline & (1) & $(2)$ & (3) & $(4) \neq$ \\
\hline Containers of P\&Ns $(1,000,000 s)$ & $\begin{array}{l}-0.636^{* * *} \\
(0.210)\end{array}$ & $\begin{array}{l}-1.138^{* * *} \\
(0.431)\end{array}$ & $\begin{array}{l}-2.528^{* * *} \\
(0.953)\end{array}$ & $\begin{array}{l}-2.154^{* * *} \\
(0.967)\end{array}$ \\
\hline Yield (containers/acre) & $\begin{array}{c}0.208 \\
(0.195)\end{array}$ & $\begin{array}{c}0.111 \\
(0.343)\end{array}$ & & \\
\hline Grows peaches only & $\begin{array}{l}-0.096 \\
(0.151)\end{array}$ & & $\begin{array}{l}-0.445 \\
(0.454)\end{array}$ & $\begin{array}{l}-0.264 \\
(0.443)\end{array}$ \\
\hline Grows nectarines only & $\begin{array}{c}0.125 \\
(0.253)\end{array}$ & & $\begin{array}{c}0.170 \\
(0.318)\end{array}$ & $\begin{array}{c}0.275 \\
(0.331)\end{array}$ \\
\hline Grows Ps or Ns only & & $\begin{array}{c}0.338 \\
(0.269)\end{array}$ & & \\
\hline Business type is partnership & & $\begin{array}{c}0.497^{*} \\
(0.276)\end{array}$ & & \\
\hline Other business structure & & $\begin{array}{l}0.512^{* *} \\
(0.242)\end{array}$ & & \\
\hline Income from P\&Ns (\%) & & & $\begin{array}{l}-0.021^{* *} \\
(0.009)\end{array}$ & $\begin{array}{l}-0.017^{*} \\
(0.009)\end{array}$ \\
\hline P\&N output that's organic (\%) & & & $\begin{array}{c}0.008^{*} \\
(0.005)\end{array}$ & $\begin{array}{c}0.007^{*} \\
(0.004)\end{array}$ \\
\hline Farm income $>\$ 500 \mathrm{k}$ & & & $\begin{array}{l}-0.032 \\
(0.596)\end{array}$ & $\begin{array}{c}0.126 \\
(0.501)\end{array}$ \\
\hline Years growing P\&Ns & & & $\begin{array}{c}0.017 \\
(0.019)\end{array}$ & $\begin{array}{c}0.018 \\
(0.014)\end{array}$ \\
\hline Farming is sole occupation & & & $\begin{array}{c}-0.136 \\
(0.370)\end{array}$ & $\begin{array}{r}-0.092 \\
(0.282)\end{array}$ \\
\hline Education is less than bachelors & & & $\begin{array}{r}-0.273 \\
(0.490)\end{array}$ & $\begin{array}{r}-0.387 \\
(0.479)\end{array}$ \\
\hline County controls & Y & Y & $\mathrm{N}$ & $\mathrm{N}$ \\
\hline$N$ & 104 & 47 & 33 & 33 \\
\hline Pseudo $R^{2}$ & 0.12 & 0.34 & 0.54 & \\
\hline $\begin{array}{l}\text { Dependent variable: } 1=\text { votes for continua } \\
\text { Weighted to account for nonresponse bias. } \\
p<0.10 \text {, ** } p<0.05 \text {, *** } p<0.01 \text {. }\end{array}$ & $\begin{array}{l}\text { = votes against } \\
\text { rd errors in par }\end{array}$ & $\begin{array}{l}\text { nuation. } \\
\text { ses. }\end{array}$ & & \\
\hline
\end{tabular}

type. From both columns, we see that voters with more containers of peach and nectarine production were less likely to support continuation of the marketing order after controlling for other factors. In column 2, we see that voters using a corporation structure (the omitted business type category) were less likely to vote for continuation than voters using partnerships and other business structures. This result suggests that business type was important or it was related to other characteristics that might have influenced vote choice. Surprisingly, we found the relationship between business type variables and quantity of peach and nectarine production to be relatively weak (with a correlation of 0.22 at most), which suggests that a relationship between these variables is not driving this result. This finding that business type is significant on its own suggests an area for future research. In general, corporations are becoming more common in California agriculture and represented about $10 \%$ of California farms in the 2017 Census of Agriculture, up from about $6 \%$ in 1997. However, the share of these corporations that are familyheld has remained study at about $84 \%$.

We report the results from unweighted and weighted regressions using the survey data in columns 3 and 4 (table 3). We included containers of peaches and nectarines and an indicator of gross income from farming. Similar to the ballot regressions, the survey regressions point to a significant negative relationship between the quantity of peach and nectarine production and the probability of voting for continuation. We also found a significant and negative relationship between the percentage of farm income from the peach and nectarine operation (a measure of farm specialization) and the probability of voting for continuation. These results provide evidence that farm size and specialization both relate to vote choice. However, the indicator of gross income from farming is not significant - we did not see much difference between the results in columns 3 and 4 . This is likely because the reweighting procedure we used mitigates only some of the nonresponse bias.

We also found that survey respondents producing a greater share of their peach and nectarine production organically were significantly more likely to support continuation. The reasons for this result are unclear from the qualitative survey responses. One possible reason could be that production research conducted by the CTFA had specific positive benefits for organic operations. For example, research on pest pressures conducted by the CTFA could perhaps benefit organic operations who were more restricted in their pest mitigation practices than conventional operations. This result could also be due to the low number of organic respondents. Only nine of the 11 organic producers who responded to our survey provided information about their vote choice. Of these nine, six voted for continuation of the marketing orders.

In our examination of farmer characteristics, we found that neither specialized experience in peach 
and nectarine production nor level of education had a significant relationship with the probability of voting for continuation. Farming as a sole occupation was also not significant.

\section{Changes made after termination}

These results point to distinct differences in farmers' perceptions of the benefits provided by the marketing orders, which raises the question of whether - and which - farmers changed their behavior post-termination. Accordingly, we compared post-termination activities of respondents voting for and against continuation using several statistical tests (details available upon request). It is important to note that these changes were not necessarily a result of marketing order termination; other factors that have affected the industry since then very likely played a role as well.

One aspect of production the survey asked about was fruit quality. Although not specifically defined in the survey, in the marketing orders fruit quality had long been measured in terms of grades, which are determined by a combination of maturity, shape, color and amount of physical damage (e.g., cracking, bruising or physical damage from pests, harvesting or other external sources). About 19\% of respondents (seven out of 36) indicated they produced a greater range of peach and nectarine qualities after the marketing orders were terminated. Another (potentially overlapping) 25\% (nine out of 36) indicated they produced higher quality fruits on average. Only one respondent reported decreasing average quality. About $16 \%$ of respondents (six out of 38) increased their advertising post-termination, while only one respondent reported decreasing advertising. About $25 \%$ of respondents (10 out of 40 ) increased their research post-termination, and only $10 \%$ (four out of 40) decreased it.

Only the change to produce higher qualities of fruit on average was significantly different across voting groups; those producing higher qualities of fruit on average after termination were less likely to have voted for continuation. This result is consistent with the trend toward higher quality that preceded marketing order termination but a little perplexing, given that restrictions on growers had been lifted in 2007 and only inspections associated with the voluntary California Well Matured label remained in effect in 2011 when the marketing orders were terminated. We can think of two possible reasons for this result. First, since the survey data were collected several years after termination, respondents could be responding to the question as if it was asking about behavior after termination of the mandatory inspections in 2007 and not after termination of the orders in 2011. Alternatively, it may be that the absence of an assessment payment and inspection costs resulting from the termination of the marketing order freed up resources for farmers to improve their fruit quality. Furthermore, in the absence of the California Well Matured label, producers who were using this label and the associated quality standard may have needed to increase their qualities to meet buyers' needs.

In addition, more than two-thirds of survey respondents ( 25 out of 35 ) indicated the CTFA was an important source of information, and more than $46 \%$ of respondents (16 out of 35) had not found a source to replace it by 2015 . However, nearly all those voting for continuation (13 out of 14) found the CTFA to be an important information source, compared with only $57 \%$ of those voting for termination (12 out of 21 ). Differing levels of access to information has significant implications. Firms that have more information may have an advantage, or even if everyone has information they may not be able to take advantage of it easily. Furthermore, peaches and nectarines are perennials and do not produce fruit immediately once planted, so these percentages may understate the share of producers (some of whom may not have been eligible to vote in the referendum) who would value this information, which may have been important for long-term production planning

Finally, we will note that of the 65 original responses received in 2015, 16 (or 24.6\%) indicated they had stopped producing fresh peaches and nectarines or exited the stone fruit industry entirely since the 2011 termination vote, highlighting the continued consolidation in the industry discussed earlier. Although all these results should be interpreted with caution due to our small sample size and the length of time elapsed between the vote and survey data collection, our data on the population of referendum voters collected at the time of the referendum, together with our survey data, can provide some useful insights.

\section{Resources lost in termination}

Several important results bear further consideration. First, even after controlling for other factors, the findings that (1) farmers who produced more and (2) farmers who had a higher percentage of gross income from peaches and nectarines were less likely to vote for continuation are consistent with the narrative that farmers were bringing the activities of the marketing orders inhouse, which reiterates the different impacts marketing orders can have on different sizes and types of farms. Second, the result that referendum voters using a corporation business structure were less likely to vote for continuation, even after controlling for size, was unexpected. This suggests the business structure that farms choose is inextricably linked to its marketing decisions and highlights the possibility that farms incorporated as corporations face different incentives.

Third, our survey data suggest that the CTFA was significantly more important as a source of information to respondents voting for continuation. The termination of the orders and dissolution of the CTFA that followed led to the end of this information collection. Finding new sources of information likely has been 
challenging for these farmers; some respondents reported having not found a replacement 4 years after termination of the orders. The post-termination information environment could have further contributed to decline in the industry, as the lack of information forced farmers to face more uncertainty and risk in marketing.

Finally, respondents with more organic production were significantly more likely to vote for continuation. This result suggests that despite efforts to create separate organizations supporting the organic industry alone, such as the failed 2018 attempt to implement a multi-crop Organic Promotion Check-Off, the peach and nectarine marketing orders may have provided benefits to organic farmers.

These findings together suggest important resources may have been lost due to termination of the two marketing orders, and not all of these resources have been replaced by other entities. While many of our results are consistent with those of the USDA, our results suggest a more complex and nuanced story in the industry and help explain some of the reasons that such a large share of growers - nearly two- thirds - actually voted for continuation of the marketing orders. In the case of this particular marketing order, it would appear to be smaller farms that lost out from termination, although this is by no means true across all marketing orders (Plakias and Goodhue [2015] provide examples where the opposite is true as well). In industries diverse in terms of farm size, production type and more, these tensions will always be present in mandatory organizations. Modern organizations that seek to continue operations must adapt to meet the diverse and evolving needs of the growers in their industries. CA

Z. Plakias is Assistant Professor, Department of Agricultural, Environmental and Development Economics, The Ohio State University; R. Goodhue is Department Chair and Professor, and J. Williams is Professor, Department of Agricultural and Resource Economics, UC Davis.

\section{References}

Crespi JM. 2003. The generic advertising controversy: How did we get here and where are we going? Rev Agric Econ 25:294-315. https://doi. org/10.1111/1467-9353.00140 Crespi JM, Sexton RJ. 2001. Marketing orders and brand promotion...Got lawyers? Choices 16:18-23.

[CTFA] California Tree Fruit Agreement. 1958. CTFA Annua Report. Retrieved from collection at University of California Davis Agricultural and Resource Economics Library.

CTFA. 1983. CTFA Annual Report. Retrieved from collection at University of California Davis Agricultural and Resource Eco nomics Library.

CTFA. 2007. CTFA Annual Report. Retrieved from collection at University of California Davis Agricultural and Resource Economics Library.
Federal Register. 2007. Nectarines and peaches grown in California; Revision of handling requirements for fresh nectarines and peaches. Federal Register 72:49128-34. www. federalregister.gov/documents/ 2007/08/28/07-4161/

nectarines-and-peaches-grownin-california-revision-ofhandling-requirements-forfresh-nectarines

Federal Register. 2010. Nectarines and peaches grown in California; Increased assessment rates. Federa Register 75:31275-9. www. federalregister.gov/documents /2010/06/03/2010-13333/ nectarines-and-peachesgrown-in-california-increasedassessment-rates

Federal Register. 2011a. Nectarines and peaches grown in California; Suspension of handling requirements. Federal Register 76:21615-8. www. federalregister.gov/documents/2011/04/18/2011-9328/ nectarines-and-peaches-grownin-california-suspension-ofhandling-requirements
Federal Register. 2011 b. Nectarines and fresh peaches grown in California; Termination of Marketing Order 916 and the peach provisions of Marketing Order 917. Federal Register 76:66602-6. www. federalregister.gov/documents/ 2011/10/27/2011-27286/ nectarines-and-fresh-peachesgrown-in-california-termination of-marketing-order-916-andthe-peach

Liaukonyte J, Richards TJ, Kaiser HM, Rickard BJ. 2014. Undercontribution to generic advertising due to self-interested inequity aversion. Eur Rev Agric Econ 42:473-97. https://do org/10.1093/erae/jbu032

McLaughlin EW, Kaiser HM, Rickard BJ. 2014. Promoting fresh produce: A losing battle? Agribusiness 30:370-84. https:/ doi.org/10.1002/agr.21378

Menayang A. 2016. With a new federal marketing order, can pecans become the next 'it' nut? Food Navigator-USA. www.foodnavigator-usa.com Article/2016/08/22/USDAapproves-Federal-MarketingOrder-for-pecan-industry
[NASS] National Agricultural Statistics Service, United States Department of Agriculture. 2020 Quick Stats. http://quickstats. nass.usda.gov/

Plakias Z, Goodhue RE. 2015. Producer heterogeneity and voting power in mandatory US agricultural marketing organisations. Eur Rev Agric org/10.1093/erae/jbv025

Sparks B. 2014. California stone fruit market steady after rocky years. Growing Produce. www growingproduce.com/fruits/ california-stone-fruit-marketsteady-after-rocky-years

U.S. Supreme Court. 2013. Horne v. Department of Agriculture. 569 U.S. (No. 12-123). Transcript of oral argument. www.supremecourt.gov/oral_arguments/ argument_transcripts/2014/14275_2b8e.pdf

U.S. Supreme Court. 1997. Glickman v Wileman Brothers \& Elliott, Inc. 521 U.S. 457. www.loc.gov/ item/usrep521457/
Warren E. 2019. Leveling the playing field for America's family farmers. https://elizabethwarren.com/plans/americas-familyfarmers

Williams GW, Capps Jr O. 2006. Overview: Commodity checkoff programs. Choices 21(1):53-4. www.choicesmagazine. org/2006-2/checkoff/2006-2-01. htm

Zheng Y, Bar T, Kaiser HM. 2010. Generic advertising in an asymmetric cournot oligopoly. Am J Agric Econ 92:740-54. 